\title{
Effects of Land Use Types on Selected Soil Properties in Central Highlands of Ethiopia
}

\author{
Daniel Jaleta Negasa \\ Ethiopian Environment and Forest Research Institute, Central Ethiopia Environment and Forest Research Center, \\ P.O. Box: 33042, Addis Ababa, Ethiopia
}

Correspondence should be addressed to Daniel Jaleta Negasa; danieljaleta1@yahoo.com

Received 17 October 2019; Revised 14 January 2020; Accepted 11 February 2020; Published 31 March 2020

Academic Editor: Davey Jones

Copyright ( $) 2020$ Daniel Jaleta Negasa. This is an open access article distributed under the Creative Commons Attribution License, which permits unrestricted use, distribution, and reproduction in any medium, provided the original work is properly cited.

\begin{abstract}
Rapid land use changes have been observed in recent years in central Ethiopia. The shift from natural ecosystem to artificial ecosystem is the main direction of change. Therefore, this study was initiated to assess the effects of land use types on selected soil properties in Meja watershed, central highlands of Ethiopia. The randomized complete block design, including three adjacent land use types as treatments with three replications and two soil depths $(0-15$ and $15-30 \mathrm{~cm})$, was applied in this study. There were significant differences in some soil properties among the three land use types. Lower soil $\mathrm{pH}$ and electric conductivity were observed in cultivated land soils than Eucalyptus woodlots soils. This has indicated the worsening soil conditions due to the shift from Eucalyptus woodlots to cultivated land. Less decomposition rate of the Eucalyptus leaves and debris collection for fuel could result in lowest soil organic carbon at the upper layer of Eucalyptus woodlot soils. However, the highest soil organic carbon at the lower layer was observed in Eucalyptus woodlot soils. The presence of highest soil potassium, cation exchange capacity, and exchangeable potassium in cultivated land soil was related to application of artificial fertilizers. Grassland soils have highest exchangeable sodium at the lower layer while highest soil carbon and sum cations at the upper layer, which can be related to the grass root biomass return and less surface runoff on grassland. There was the highest exchangeable sodium percentage on Eucalyptus woodlot soils at the upper layer; it can be due to the less surface nutrient movement and growth characteristics of the tree. The soils in cultivated land was shifted to more acidic and less electric conductivity.This shift can lead to soil quality deterioration that affects the productivity of the soils in the future.Nutrient leaching, application of artificial fertilizer, soil erosion, and continuous farming have affected the soil properties in cultivated land. The presence of highest exchangeable sodium percentage and lowest sum of cations at the upper layer of soil in Eucalyptus woodlot should be noted for management and decision makers. The previous negative speculations on Eucalyptus woodlots which can be related with the soil texture, soil moisture, bulk density, total nitrogen, exchangeable magnesium, calcium, and available sulfur should be avoided because there were no significant differences observed among the three land use types in the study area. The study recommends further studies on the effects of Eucalyptus on soil properties by comparing among different ages and species of Eucalyptus. Finally, planting of Eucalyptus on central highlands of Ethiopia should be supported by land use management decision.
\end{abstract}

\section{Introduction}

Land use, which is human driven activities on land, is one of the major characteristics of land [1]. Land use type could determine the total production from the land and the status of the producer. The land use type could be determined by the need of producer, the environmental condition (soil, climate, rainfall, altitude, etc.), socioeconomic status (land lord, tiller, or peasant), and political (tenure, land policy, and ownership) and cultural manners (beliefs, norms, and bylaws on the land) of the given area [2,3]. The aforementioned factors could influence the owner to decide the type of land use on their land. Among the factors that could influence the user's preference is the soil condition of the field. The soil condition can be identified by analyzing the soil properties and comparing with the standards. 
Rapid population growth is believed to influence the type of land use and the rate of expansion of specific land use type $[3,4]$. This could affect the soil properties of a given land when it is changed from natural to artificial land use system or vice versa. The intensified agricultural land expansion on the expense of the loss natural environment could also lead to severe land degradation. In the central highlands of Ethiopia, there is significant land use change from natural ecosystem to artificial ecosystem within five decades [5-7]. Recently, Eucalyptus woodlot has joined the artificial ecosystem with rapidly expanding on grassland, woodland, riverside wetlands, cultivated land, and degraded land in the central highlands of Ethiopia [6-10].

Eucalyptus, as economic and social problem relieving tree species, is expanding in the central highlands of Ethiopia $[6,7,9,11]$. The species was planted in the highlands of Ethiopia in the end of $19^{\text {th }}$ century as the source of fuel wood for the settlers of the newly established capital city of Ethiopia [12]. In some places, it has expanded to $18 \%$ within 30 years with farmers' demand [9, 10, 13]. Eucalyptus has benefited farmers with filling household fuelwood demand, improving income, and providing social and cultural value and environmental benefits. [14-16]. However, many still did not accept its planting by raising concerns on its impacts such as water consumption, nutrient competitiveness, soil erosion, and land degradation [10, 17-19].

Various studies have been done to quantify the effect of land use types on soil properties in Ethiopia $[3,9,11,20-22]$. Some have compared the natural forest and woodland with the artificial land uses [3, 20]. Furthermore, some studies have compared the effects of different cultivated land along ages on soil properties [20, 21]. The effects of plantation forest and natural forest on soil properties were also studied [23]. Some have compared the effects of conserved areas, cultivated land, plantation, and natural forest on soil properties. Zerfu et al., [24] have compared the effect of Eucalyptus on soil properties before and after harvesting. Chanie et al. [10] have studied the variation of soil properties along different distances from Eucalyptus tree. Some have compared the effect of Eucalyptus along ages [25].

However, the effects of land use types, comparing the effects of natural land use (grassland) and the artificial land use (cultivated land and Eucalyptus woodlots) on soil, were less studied in the central highlands of Ethiopia and elsewhere. Thus, the farmers' Eucalyptus planting trend is increasing with the expansion of natural and cultivated land. Currently, due to its social and economic benefits, it is difficult to hinder farmers to not plant Eucalyptus on their land $[13,26-28]$. However, it is beneficial to understand the effects of the land use types on soil properties to support generating land use management options. Therefore, the objective of this study was to assess the effects of land use types on selected soil properties in the central highlands of Ethiopia.

\section{Methods}

2.1. Description of the Study Area. The study was conducted at Meja watershed in West Shewa zone, Central Ethiopia. It is found $110 \mathrm{~km}$ west of the capital, Addis Ababa (Figure 1). The watershed is found in two districts: Jeldu and Dendi. The watershed is located within $9^{\circ} 07^{\prime}$ to $9^{\circ} 17^{\prime} \mathrm{N}$ and $38^{\circ} 02^{\prime}$ to $38^{\circ} 07^{\prime} \mathrm{E}$, with an altitude ranging from 2400 to $3200 \mathrm{~m}$ above mean sea level. The watershed is also found in southern upper Blue Nile basin. The total area of the watershed is 10107 ha.

The mean annual temperature ranges from $17^{\circ} \mathrm{C}$ to $25^{\circ} \mathrm{C}$. The rainfall is bimodal with the short rainy season from February to May and long rainy season from June to September. The mean annual rainfall is $1400 \mathrm{~mm}$ though there is variation of rainfall amount along the altitude. The agroecology of the site is grouped locally under Dega and Wurch (cool highlands with sufficient rainfall, with some extreme cool weather condition). Eucalyptus globulus is the main exotic tree planted in the watershed. Very few places are covered by small patches of natural forest; otherwise, bushlands are dominated the riversides, ridges, and steep slope. Scattered trees are still visible on cultivated land and grassland. Acacia abyssinica, Hagenia abyssinica, and Buddleja polystachya are some of the indigenous trees and shrubs in the area. Eucalyptus globulus woodlots are abundant in the watershed replacing bush land, cultivated land, and marginal grazing lands.

The major river in the watershed is the Meja River, which is one of the tributaries of the Nile River. The Meja River originates at high altitude just near Galessa village in the Dendi district. The head waters are in a flat wide valley, which is a wetland heavily utilized for livestock grazing in Galessa. Many tributaries drain into the Meja river from both the east and west sides of the watershed. The river flows throughout the year with high flow at July, August, and September. The southern upper Blue Nile, which includes the study area, is dominated by Vertisol. The soil in the study area is classified under Pellic Vertisol. The textural class of the soil at upper section of the watershed is dominated by clay loam and clay soil. The lower section of the watershed has loam soil. The soil textural class of this study area is clay soil. The soil $\mathrm{pH}$ value ranges from 4.9 to 5.9 , which is moderately acidic soil. Soil erosion by water is common threat for sustainability of cultivated land in the study area.

The land use of the area is predominantly mixed croplivestock-tree production system. Major crops grown in the area are barley (Hordeum vulgare), wheat (Triticum vulgare), potato (Solanum tuberosum), and maize (Zea mays). Livestock production (cattle, sheep, and horses) for various purposes is also practiced. Eucalyptus plantations and woodlots are produced mainly for sale in the study area. The major cash sources for farmers in the watershed are from sale of potato and Eucalyptus. The estimated population of the study area is 42000. The estimated annual population growth is $2.5 \%$. The average number of people per household is 6 people. Landholding size per household ranges from 0 to 4 hectares. Half of the population are youth in the study area.. Majority of the population live in the rural area.

2.2. Experimental Design. The comparison of the effects different land use types on selected soil properties was 

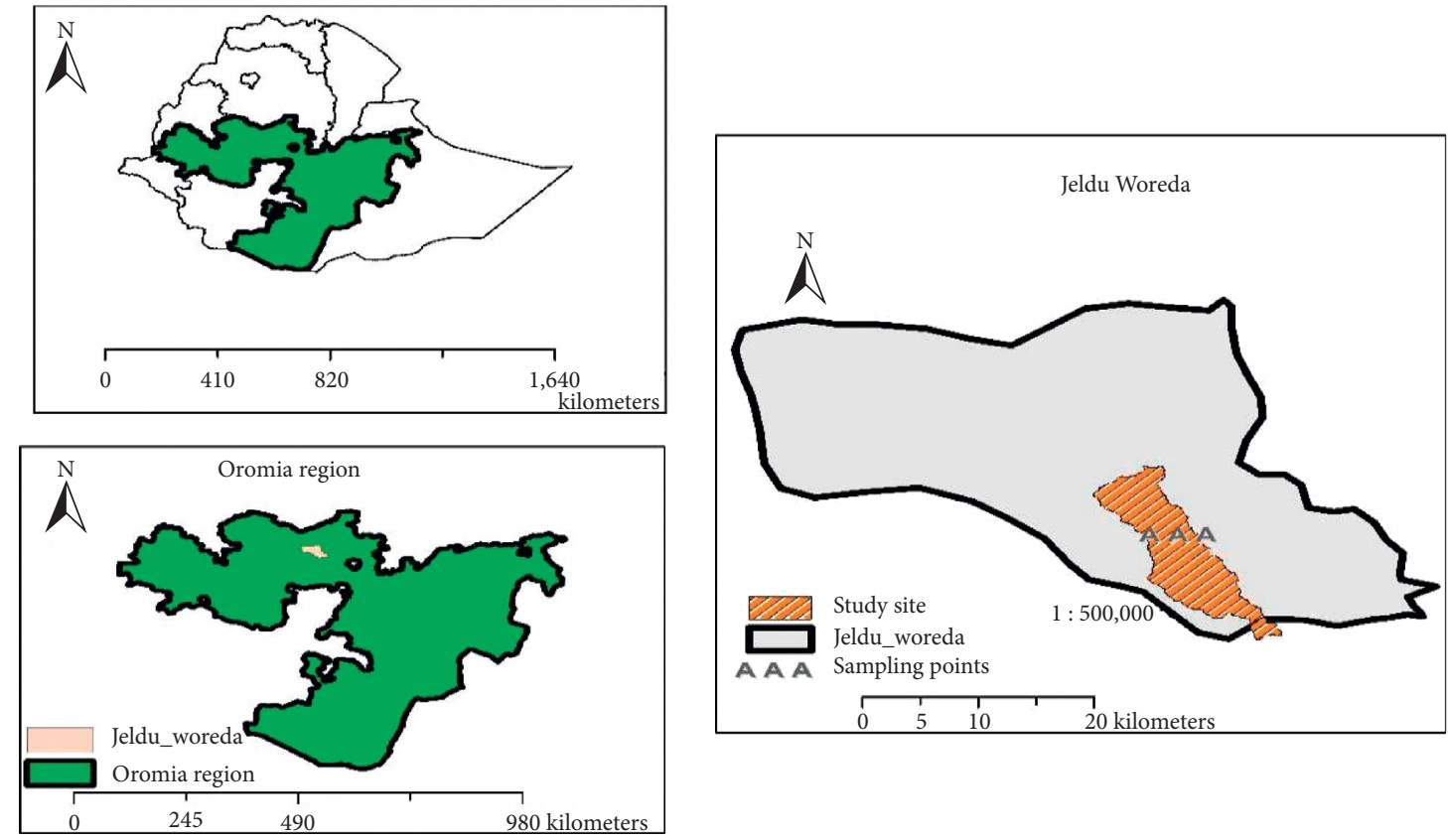

Figure 1: Map of the study area.

studied by collecting soil samples from three different land use types. The experimental design for this study was randomized complete block design (RCBD) in which the land use types were considered as treatments. Three land use types, namely, Eucalyptus woodlot, cultivated land, and grassland, were selected for comparison as treatments. Grassland was considered as control treatment in the study.The three adjacent land use types, which shares similar biophysical condition such as soil and slope, are grouped in a block. . Four replications of each land use type were used in the four different sites forming a total of twelve sample plots.

2.3. Soil Sampling. The soil samples were collected only one time from three land use types at four different sites in Meja watershed, Jeldu district. From each site, three soil sampling locations were systematically selected with having three adjacent land use types. The three land use types within each site have similar topography and other conditions, which made the local soil forming factors relatively uniform (Table 1). The soil samples were collected at twelve points with four replications of land use types in the study area. Plot with square dimension $(20 \mathrm{~m} \times 20 \mathrm{~m})$ was laid at the middle of each land use types. The pits were dug at four corners and center of the plots using auger, and two soil samples were taken from the pit at two soil depths $(0-15 \mathrm{~cm}$ and $15-30 \mathrm{~cm})$.

2.4. Soil Laboratory Analysis. The collected soil samples were bulked to one composite sample with similar depth at each plot of the land use types. Two composite soil samples were collected from each land use types. In total, six composite samples were collected from each site and twenty-four composite samples were collected from the study site. The composited sample that weighs one kilogram was taken, properly labelled, and packed with plastic bags prior to transporting it to laboratory.

For bulk density and moisture analysis, two soil samples at depths $0-10 \mathrm{~cm}$ and $20-30 \mathrm{~cm}$ were taken using core sampler (height $=10 \mathrm{~cm}$ and diameter $=7.2 \mathrm{~cm}$ ) and their weight was also measured directly at the field. The soil samples were collected in a labelled polyethylene bag, registered, and transported to soil laboratory of water works design and supervision enterprise at Addis Ababa, Ethiopia. All soil samples were air-dried at room temperature and sieved (mesh size $2 \mathrm{~mm}$ ).

Soil organic carbon (OC) was determined using the Walkley and Black method as stated in Nelson and Sommers [29]. Total nitrogen (TN) was estimated by the Kjeldhal method as used by Bremner [30]. The soil texture was determined using the hydrometer method [31]. Soil pH was determined by a $\mathrm{pH}$ meter. Electrical conductivity of the soil was determined on the saturated paste. Bulk density was determined by dividing the oven dry mass $\left(105^{\circ} \mathrm{C}\right)$ by the volume of the core. Exchangeable cations $\left(\mathrm{Ca}^{2+}, \mathrm{K}^{+}, \mathrm{Mg}^{2+}\right.$, and $\mathrm{Na}^{+}$) were determined using $1 \mathrm{M}$ ammonium acetate at $\mathrm{pH}$ of 7.0 [32]. Cation exchange capacity (CEC) was calculated by summing up the charge concentrations of $\mathrm{Ca}^{2+}, \mathrm{K}^{+}$, $\mathrm{Mg}^{2+}$, and $\mathrm{Na}^{+}$. Available potassium $(\mathrm{K})$ was determined by flame photometer with dissolved $0.3728 \mathrm{~g}$ of dried $\mathrm{KCl}$ in one litre of extracting solution [33]. Exchangeable sodium percentage (ESP) was computed by dividing exchangeable sodium by soil CEC and multiplying by 100 . Available sulfur of the soil was extracted by the Mehlich-3 multinutrient extraction method [34]. Available phosphorus was determined by the Bray 2 method [35].

2.5. Statistical Analysis. The soil laboratory results were analyzed with Statistical Package for Social Sciences (SPSS) 
TABLE 1: Mean of biophysical conditions of the sampling plots.

\begin{tabular}{|c|c|c|c|c|c|c|c|c|c|c|}
\hline \multirow{2}{*}{$\begin{array}{l}\text { Land use } \\
\text { types }\end{array}$} & \multirow{2}{*}{$\begin{array}{c}\text { Moisture } \\
\text { content (\%) }\end{array}$} & \multirow{2}{*}{$\begin{array}{l}\text { Soil } \\
\text { temp. } \\
\left({ }^{\circ} \mathrm{C}\right)\end{array}$} & \multirow{2}{*}{$\begin{array}{l}\text { Slope } \\
\text { degree } \\
\left({ }^{\circ}\right)\end{array}$} & \multirow{2}{*}{$\begin{array}{l}\text { Stone } \\
\text { cover } \\
(\mathrm{cm})\end{array}$} & \multicolumn{3}{|c|}{ Ground cover (count) } & \multirow{2}{*}{$\begin{array}{l}\text { Crown } \\
\text { cover } \%\end{array}$} & \multirow[b]{2}{*}{ Plant type } & \multirow{2}{*}{$\begin{array}{c}\text { Planting } \\
\text { characteristics }\end{array}$} \\
\hline & & & & & Weed & Stubble & $\begin{array}{l}\text { Organic } \\
\text { residues }\end{array}$ & & & \\
\hline $\begin{array}{l}\text { Cultivated } \\
\text { land }\end{array}$ & 9.6 & 26.7 & 9.0 & 5.6 & 75.5 & 301.25 & 4.8 & - & $\begin{array}{c}\text { Wheat (Triticum } \\
\text { vulgare), }\end{array}$ & $\begin{array}{l}\text { Hand sown seeds and } \\
3 \text { months }\end{array}$ \\
\hline Grassland & 16.2 & 24.9 & 10.5 & - & 32.8 & - & 14.2 & - & $\begin{array}{c}\text { Chomo grass } \\
\text { (Brachiaria } \\
\text { humidicola) }\end{array}$ & $\begin{array}{c}\text { Naturally grown and } \\
\text { never tilled }\end{array}$ \\
\hline Eucalyptus & 14.1 & 25.5 & 9.5 & 14.7 & 86.5 & - & 385.0 & 48 & $\begin{array}{c}\text { Tasmanian blue } \\
\text { gum (Eucalyptus } \\
\text { globulus) }\end{array}$ & $\begin{array}{c}2 \text { meters apart, } 4 \\
\text { years old, } 8 \text { meter } \\
\text { height, and } 10 \mathrm{~cm} \\
\text { DBH }\end{array}$ \\
\hline
\end{tabular}

software version 20 [36]. The data were tested for normality prior to analysis. Analysis of variance (ANOVA) test was run using the multivariate general linear model to test the effects of land use type on dependent variables. Significant means were separated using least significant difference (LSD) at 5\% significance level for pair wise comparison of means to assess the mean differences of the land uses and depth levels depending on soil chemical properties.

\section{Results}

3.1. SoilpH, EC, Texture, Moisture, and Bulk Density. The $\mathrm{pH}$ $\left(\mathrm{H}_{2} \mathrm{O}\right)$ of the soils in the three land use types is grouped under strongly acidic (5.1-5.5) class. There was a significant difference $(p \leq 0.05)$ in soil $\mathrm{pH}$ among land use types in both layers (Table 2). The $\mathrm{pH}$ of soils in grassland $>$ Eucalyptus woodlot $>$ cultivated land in upper layer and the $\mathrm{pH}$ of grassland $>$ cultivated land $>$ Eucalyptus woodlot in the lower layer. The soil EC of the study site ranges from $0.75-0.92 \mathrm{mS} / \mathrm{cm}$; this could indicate that it is grouped into the soil salinity class of nonsaline soil. The EC of the soils could depend on the amount of moisture present in the soil. There was a significant difference $(p \leq 0.05)$ in soil EC among land use types in the upper layer (Table 2). The grassland soils had the highest EC value in the upper layer, while cultivated land soils had the lowest EC value in the upper layer as compared to others.

There was no significant difference $(p \leq 0.05)$ in soil moisture, texture, and bulk density among land use types in both layers (Table 2). The soils of the study area are grouped under clay class according to USDA classification. There was highest soil moisture content in grassland at the upper layer, while the highest soil moisture content was observed in eucalyptus woodlot soil in the lower layer. Cultivated land had the highest bulk density value in both layers, while grassland had the lowest bulk density in both layers as compared to others.

3.2. Soil Organic Carbon, Total Nitrogen, Potassium, and Available $S$ and $P$. The results of soil organic $\mathrm{C}$, total $\mathrm{N}$, potassium, and available $S$ and $P$ are listed in Table 3. There was a significant difference $(p \leq 0.05)$ in soil organic carbon content among land use types in the upper layer (Table 3 ).
The soil organic carbon content of grassland $>$ cultivated land $>$ Eucalyptus woodlot in the upper layer. The upper surface of the soils in grassland contains higher soil organic carbon than in the lower surface. There was higher soil organic carbon deposition in the Eucalyptus woodlot soils at the lower layer. However, there was less soil organic carbon on Eucalyptus woodlots in the upper surface as compared to the other two land use types.

Soil potassium is classified as macronutrient that is an essential nutrient for plant growth. There was a significant difference $(p \leq 0.05)$ in soil potassium content among land use types in the lower layer (Table 3 ). Cultivated land soils had highest potassium content in the lower layer, while grassland soils had lowest potassium content in the lower layer. However, there was no significant difference in soil potassium content among land use types in the upper layer. The soil CEC of the study site $(21.1-31.6 \mathrm{meq} / 100 \mathrm{~g})$ is rated as high based on its value [37]. There was a significant difference $(p \leq 0.05)$ in soil CEC among Eucalyptus woodlot, cultivated land, and grassland in the upper layer (Table 3). The CEC of cultivated land $>$ grassland $>$ Eucalyptus woodlot in the upper layer. There was no significant difference $(p \leq 0.05)$ in total nitrogen, available $S$, and available $P$ among land use types in both layers (Table 3). Grassland had highest total nitrogen content in both layers, while Eucalyptus woodlot soils had total nitrogen content in both layers. Cultivated land and eucalyptus had the highest and lowest available $S$, respectively, in both layers. Eucalyptus woodlots had highest available P, while grassland had the lowest available $\mathrm{P}$ in both layers.

3.3. Soil Exchangeable Cations ( $\mathrm{Na}, \mathrm{K}, \mathrm{Ca}$, and $\mathrm{MG}$ ), Sum of Cations, and ESP. There was a significant difference $(p \leq 0.05)$ in soil exchangeable sodium among land use types in the lower layer. The exchangeable $\mathrm{Na}^{+}$soils of grassland $>$ Eucalyptus woodlot $>$ cultivated land in the lower layer (Table 4). The exchangeable potassium level of the soils in the study area could be grouped under low category $\left(0.2-0.4 \mathrm{cmol}(+) / \mathrm{kg}\right.$ of $\left.\mathrm{K}^{+}\right)$. There was a significant difference $(p \leq 0.05)$ in soil exchangeable potassium among land use types in the lower layer (Table 4). Cultivated land soils had the highest soil exchangeable potassium, while grassland soils had lowest soil exchangeable potassium in the upper layer. The sum of cations is directly related with CEC 
TABLE 2: Mean $( \pm$ SEM) of selected soil physical properties across land uses and soil depths.

\begin{tabular}{|c|c|c|c|c|c|c|c|c|c|}
\hline Land uses & $\begin{array}{l}\text { Depth } \\
(\mathrm{cm}\end{array}$ & $\begin{array}{c}\mathrm{pH} \mathrm{H}_{2} \mathrm{O} \\
(1: 2.5)\end{array}$ & $\begin{array}{c}\mathrm{EC}(\mathrm{mS} / \mathrm{cm}) \\
(1: 2.5)\end{array}$ & $\%$ clay & Texture & $\%$ silt & $\begin{array}{c}\text { Texture } \\
\text { Class } \\
\text { (USDA) }\end{array}$ & $\begin{array}{l}\text { Soil moisture } \\
(\%)\end{array}$ & $\begin{array}{c}\text { Soil } \\
\text { bulk density } \\
\left(\mathrm{g} / \mathrm{cm}^{3}\right)\end{array}$ \\
\hline \multirow{2}{*}{ Cultivated } & $0-15$ & $4.92 \pm 0.03^{\mathrm{a}}$ & $0.75 \pm 0.02^{\mathrm{a}}$ & 46.3 & 20.0 & 33.7 & Clay & $8.35 \pm 0.37$ & $0.25 \pm 0.03$ \\
\hline & $15-30$ & $5.23 \pm 0.14^{\mathrm{a}}$ & $0.92 \pm 0.02$ & 51.2 & 22.5 & 26.3 & Clay & $8.38 \pm 0.59$ & $0.26 \pm 0.02$ \\
\hline \multirow{2}{*}{ Eucalyptus } & $0-15$ & $5.14 \pm 0.08^{\mathrm{ab}}$ & $0.82 \pm 0.05^{\mathrm{ab}}$ & 51.3 & 15.6 & 33.1 & Clay & $7.88 \pm 1.06$ & $0.24 \pm 0.01$ \\
\hline & $15-30$ & $5.12 \pm 0.01^{\mathrm{a}}$ & $0.87 \pm 0.04$ & 46.2 & 21.3 & 32.5 & Clay & $9.98 \pm 1.38$ & $0.26 \pm 0.01$ \\
\hline \multirow{2}{*}{ Grassland } & $0-15$ & $5.35 \pm 0.11^{\mathrm{b}}$ & $0.86 \pm 0.02^{\mathrm{b}}$ & 44.4 & 24.4 & 31.2 & Clay & $8.93 \pm 0.10$ & $0.21 \pm 0.02$ \\
\hline & $15-30$ & $5.59 \pm 0.12^{\mathrm{b}}$ & $0.84 \pm 0.04$ & 51.3 & 18.1 & 30.6 & Clay & $9.55 \pm 0.24$ & $0.24 \pm 0.01$ \\
\hline
\end{tabular}

The superscripts across a column in different letters represent that they are significantly different at $p \leq 0.05$.

TABLE 3: Mean ( \pm SEM) of selected soil chemical properties across land uses and soil depths.

\begin{tabular}{lccccccc}
\hline Land uses & Depth $(\mathrm{cm})$ & OC $(\%)$ & TN $(\%)$ & K (meq/100 g) & Available S (\%) & Available P (mg/kg) & CEC (meq/100 g) \\
\hline \multirow{2}{*}{ Cultivated } & $0-15$ & $3.09 \pm 0.33^{\mathrm{a}}$ & $0.33 \pm 0.03$ & $0.41 \pm 0.09$ & $1.34 \pm 0.86$ & $2.36 \pm 0.2$ & $26.3 \pm 5.5^{\mathrm{a}}$ \\
& $15-30$ & $3.08 \pm 0.22$ & $0.29 \pm 0.02$ & $0.32 \pm 0.08^{\mathrm{a}}$ & $1.88 \pm 1.17$ & $2.77 \pm 0.6$ & $31.6 \pm 6.44$ \\
Eucalyptus & $0-15$ & $2.47 \pm 0.19^{\mathrm{b}}$ & $0.31 \pm 0.06$ & $0.21 \pm 0.02$ & $0.54 \pm 0.04$ & $3.05 \pm 1.1$ & $21.9 \pm 0.91^{\mathrm{b}}$ \\
& $15-30$ & $3.11 \pm 0.19$ & $0.29 \pm 0.02$ & $0.28 \pm 0.02^{\mathrm{ab}}$ & $0.31 \pm 0.01$ & $3.07 \pm 0.5$ & $21.1 \pm 1.06$ \\
Grassland & $0-15$ & $3.78 \pm 0.33^{\mathrm{a}}$ & $0.36 \pm 0.03$ & $0.20 \pm 0.01$ & $0.77 \pm 0.04$ & $2.44 \pm 0.3$ & $24.8 \pm 0.90^{\mathrm{b}}$ \\
& $15-30$ & $2.91 \pm 0.22$ & $0.30 \pm 0.02$ & $0.14 \pm 0.01^{\mathrm{b}}$ & $0.66 \pm 0.05$ & $1.88 \pm 0.2$ & $25.5 \pm 1.59$ \\
\hline
\end{tabular}

The superscripts across a column in different letters represent that they are significantly different at $p \leq 0.05$.

TABLe 4: Mean $( \pm$ SEM) of selected soil exchangeable cations, sum of cations, and ESP across land uses and soil depths.

\begin{tabular}{lccccccc}
\hline Land uses & Depth $(\mathrm{cm})$ & $\begin{array}{c}\text { Exch. Na } \\
(\mathrm{meq} / 100 \mathrm{~g})\end{array}$ & $\begin{array}{c}\text { Exch. K } \\
(\mathrm{meq} / 100 \mathrm{~g})\end{array}$ & $\begin{array}{c}\text { Exch.Ca } \\
(\mathrm{meq} / 100 \mathrm{~g})\end{array}$ & $\begin{array}{c}\text { Exch. Mg } \\
(\mathrm{meq} / 100 \mathrm{~g})\end{array}$ & $\begin{array}{c}\text { Sum of cations } \\
(\mathrm{meq} / 100 \mathrm{~g})\end{array}$ & $\begin{array}{c}\text { ESP } \\
\text { Cultivated }\end{array}$ \\
& $0-15$ & $2.5 \pm 0.04$ & $0.42 \pm 0.09^{\mathrm{a}}$ & $18.8 \pm 0.58$ & $6.47 \pm 0.26$ & $28.2 \pm 0.78^{\mathrm{ab}}$ & $8.96 \pm 0.27^{\mathrm{ab}}$ \\
Eucalyptus & $15-30$ & $2.45 \pm 0.04^{\mathrm{a}}$ & $0.31 \pm 0.07$ & $19.0 \pm 0.47$ & $6.05 \pm 0.01$ & $27.8 \pm 0.48$ & $8.82 \pm 0.25$ \\
& $0-15$ & $2.4 \pm 0.02$ & $0.29 \pm 0.01^{\mathrm{ab}}$ & $17.1 \pm 1.45$ & $6.68 \pm 0.73$ & $26.5 \pm 1.07^{\mathrm{a}}$ & $9.46 \pm 0.33^{\mathrm{a}}$ \\
Grassland & $15-30$ & $2.47 \pm 0.06^{\mathrm{ab}}$ & $0.23 \pm 0.02$ & $17.5 \pm 1.30$ & $6.21 \pm 0.48$ & $26.5 \pm 1.82$ & $9.48 \pm 0.57$ \\
& $0-15$ & $2.5 \pm 0.04$ & $0.23 \pm 0.02^{\mathrm{b}}$ & $20.4 \pm 1.13$ & $7.15 \pm 0.21$ & $30.2 \pm 1.32^{\mathrm{b}}$ & $8.32 \pm 0.36^{\mathrm{b}}$ \\
& $15-30$ & $2.63 \pm 0.05^{\mathrm{b}}$ & $0.19 \pm 0.01$ & $21.5 \pm 1.78$ & $7.38 \pm 0.55$ & $31.7 \pm 2.31$ & $8.44 \pm 0.62$ \\
\hline
\end{tabular}

The superscripts across a column in different letters represent that they are significantly different at $p \leq 0.05$.

because it is one part of measurement to determine CEC. As it is listed above in Table 3, the CEC of the three land use types was significantly different among each other. The sum of cations value could be varied due to the presence of other cations and soil physical condition. Thus, there was a significant difference $(p \leq 0.05)$ in sum of cations of the soils among land use types in the upper layer. Grassland soils had highest sum of cations, while eucalyptus woodlot soils had lowest sum of cations in the upper layer (Table 4).

The soil exchangeable sodium percentage (ESP) of the study site ranges from $8.3 \%$ to $9.5 \%$. If the ESP of the soil is less than $15 \%$, the soil will not be sodic. In this case, the soil of the study site was not sodic. There was a significant difference $(p \leq 0.05)$ in soil ESP among land use types in the upper layer (Table 4). Eucalyptus woodlot soils had highest ESP, while grassland soils had the lowest ESP in the upper layer.

There was no significant difference $(p \leq 0.05)$ in soil exchangeable cations calcium and magnesium among land use types in both layers (Table 4). Grassland soils had highest exchangeable calcium, while Eucalyptus woodlot soils had lowest exchangeable calcium in both layers. Grassland soils had highest exchangeable magnesium, while cultivated land soils had lowest exchangeable magnesium in both layers as compared to the others.

\section{Discussion}

4.1. Effects of Land Use Types on pH, EC, Texture, Moisture, and Bulk Density. The soils in cultivated land were more acidic than the other land use types in the upper layer. This can be due to application of ammonium-based fertilizers, erosion, and improper ploughing direction [38]. Differently, the $\mathrm{pH}$ of Eucalyptus woodlot soils was lower than that of cultivated land and grassland soils in Ethiopia [3, 11, 39, 40]. The soil $\mathrm{pH}$ can influence the solubility and availability of nutrients in the soil. The soil $\mathrm{pH}$ can vary within short distance due to nitrification, root activity, and decomposition of organic matter. According to Chemeda et al. [41], the $\mathrm{pH}$ of grassland soils was higher than that of the soils in cultivated land and forest land. But, Yimer et al. [42] have found that the $\mathrm{pH}$ of cultivated land soils was higher than that of the soils in grassland and forest land. The reason for lower soil $\mathrm{pH}$ in the Eucalyptus woodlot can be due to frequent cation uptake and removal of cations around the tree [11].

The soil EC value was related with the soil $\mathrm{pH}$ in the upper layer. The EC level can affect the soil texture, CEC, organic matter condition, and subsoil characteristics of the soils. Various studies have found higher EC in grassland soils as compared to the soils in cultivated land and other land use types [43-45]. The lower EC value in cultivated land soils can 
be related with the loss of exchangeable base from the soil due to leaching and erosion as a result of continuous farming.

4.2. Effects of Land Use Types on Selected Important Soil Nutrients. In several findings, grassland soils can accumulate higher soil carbon than other land use types except natural forest [3, 45-47]. The decomposed humus from grassroots and above-ground biomass in the upper layer of grassland soils could increase the carbon content. The upper surface of the grassland soils contains higher soil carbon than the lower surface. It is due to the presence of easily decomposing materials on the upper surface than other land use types.

In the other case, the reason behind higher soil organic carbon content in the cultivated land than Eucalyptus woodlots was due to fertilizer application and higher leaf decomposition of the cultivated crops. However, there was higher soil organic carbon in Eucalyptus woodlot than the other two land uses in the lower layer. This could be due to slow decomposing rate of Eucalyptus leaves and debris collection for fuel wood that could reduce the accumulation of organic matter under the tree canopy. Similar to this study, grassland soils had higher soil organic carbon than cultivated land in other studies $[41,42,45,47]$. This is due to the presence of numerous amounts of grass root growth and biomass turnover rate; in addition to this, less erosion and absence of tillage could lead to higher accumulation of soil organic carbon in the grassland soils. On contrary to the above, studies have found higher soil organic carbon in Eucalyptus woodlot soils than grassland and cultivated land soils in the upper layer [3, 21, 40, 48]. In general, the soil organic carbon content for the study site soils ranges from $2.47 \%-3.78 \%$, which could be grouped under optimum status.

The occurrence of higher potassium in the lower layer of cultivated land soils can be related with the application of fertilizers and the leaching of nutrient to the lower layer due to ploughing [21]. Similar findings have observed significantly higher potassium content in the cultivated land soils as compared to other land use types [45]. The soil potassium content of the study site rages from 0.16 to $41 \mathrm{meq} / 100 \mathrm{~g}$, which could be considered as very low for plant growth on the soil.

The higher CEC in the upper layer of cultivated land soils can be related with the presence of higher exchangeable sodium and potassium in the soils that can be related to the application of fertilizer. Similarly, other findings have observed higher CEC in the cultivated land soils as compared to other land use types [3]. However, Chemeda et al. [41] and Adugna and Abegaz [22] have found higher CEC in grassland soils than cultivated land soils. CEC can be related with soil carbon, clay content, and $\mathrm{pH}$ value of the soil. The lower CEC value in Eucalyptus woodlot soils can be related with the lower soils' $\mathrm{pH}$ value (more acidic soil). The other reason can be depletion of exchangeable bases in Eucalyptus and grassland soils. Application of fertilizers, which can initiate the presence of cations on cultivated land, can also affect the CEC of cultivated land soils. The value of CEC in upper layer of cultivated land is smaller than that in the lower layer; this could be resulted due to exchangeable sodium leaching.
4.3. Effects of Land Use Types on Exchangeable Cations and ESP. The result has also indicated the inverse relation of soil exchangeable sodium with soil potassium in the similar layer. This can be also related with the application of fertilizers and nutrient movement to the lower layer. In addition, it can be connected to the crop nutrient uptake for their growth. This result matches with the finding of Seyoum [44] and Feyisa et al. [45] by the higher content of soil exchangeable sodium in grassland soils as compared to the other land use types. Other studies have observed higher soil exchangeable sodium in the lower layer of the cultivated land soils as compared to the upper layer $[43,44]$. This is due to leaching of exchangeable cations, in this case, sodium. Similarly, on grassland soils, the nutrient loss can be reduced due to lesser surface water movement. So, it was observed the higher soil exchangeable sodium in grassland soils as compared to cultivated land. However, other studies have found higher soil exchangeable sodium in cultivated land soils than grassland soils in both layers [21, 43].

The aforementioned result about the soil exchangeable potassium content has shown the direct relationship of the presence of soil potassium and exchangeable potassium under similar land use type soils. The presence of higher exchangeable potassium in cultivated land soils can be related to the type of fertilizers applied on the cultivated land soils. Oppositely, Lemma and Olsen [49] have found significant variation between cultivated land and Eucalyptus woodlot soils. The result has indicated that there was higher soil exchangeable potassium in the Eucalyptus woodlot soils than cultivated land soils [3]. However, other studies have also found higher soil exchangeable potassium in the cultivated land soils as compared to other land use types [20-22].

The sum of cations in grassland soils was higher as compared to the other land use types. This is due to less surface water movement in grassland and lesser consumption of these cations by grasses. Other findings have also observed higher sum of cations in the grassland soils as compared to the other land use types [45]. In the other case, the lower sum of cations in the Eucalyptus woodlot soils at upper layer was observed which is due to the root characteristics of the tree. The Eucalyptus tree's deep roots can also influence the downward movement of these cations from the upper layer so that lower value of cations was observed in the upper layer of Eucalyptus woodlot soils.

The presence and absence of sodium in the soil can be related to the plant growth characteristics and the nutrient movement in the soil at surface layer. Here, it can be related to surface water movement and fertilizers application. A study has indicated that there was higher ESP in the cultivated land soil than grassland and other land use types [50].

\section{Conclusions}

Land use types can affect the soil properties and the presence of essential nutrients in the soils. Central Ethiopia has observed significant change in land use as a result of expansion of cultivated land and Eucalyptus woodlots. The result of this study has shown that there was a significant difference in soil properties due to the effects of land use types in the study 
area. The soil $\mathrm{pH}$ and EC have shown significant difference among the three land uses types in the upper layer. Cultivated land soils have shown lower $\mathrm{pH}$ and EC than $\mathrm{Eu}$ calyptus woodlot soils in the upper layer. This is due to the application of ammonium base fertilizers, cation loss as a result of leaching, and water erosion due to continuous farming. There was a significant difference in soil organic carbon among land use types with lowest in Eucalyptus woodlots soils in upper layer. The highest soil organic carbon was observed in lower layer of the Eucalyptus woodlot soils. This could be due to less decomposing rate of Eucalyptus leaves and the collection of debris for fuel wood, which could reduce the accumulation of organic matter in Eucalyptus woodlots. Grassland soils have highest soil organic carbon in the upper layer as a result of higher number of grass root growth and biomass turnover rate. Furthermore, there was a significant difference in soil potassium, CEC, exchangeable sodium, exchangeable potassium, sum of cations, and ESP among land use types. There was the highest potassium value in cultivated land soils as compared to others due to leaching of applied fertilizers during soil sampling. Related with this, there were highest CEC and exchangeable potassium in the upper layer of cultivated land soils. This can be related with application of fertilizer. However, exchangeable sodium was highest in grassland soils at lower layer. This can be related with leaching of nutrients from the upper layer. The highest sum of cations was seen in grassland soils at the upper layer. This can be related with less nutrient loss due to less surface runoff from the field.

The highest ESP was observed in Eucalyptus woodlot soil at the upper layer. This is due to the less surface nutrient movement and growth characteristics of the tree. In general, the study has observed important soil properties which were significantly affected due to the effects of land use types. Cultivated land soils were shifted to more acidic and lesser EC content soil, which could lead to less productive soil in the future. Nutrient leaching, application of fertilizers, soil erosion, and continuous farming have affected the soil properties in cultivated land. These effects should be managed with proper and sustainable farm management practices in order to avoid the degradation of cultivated land soils from the study area. The presence of the highest ESP and lowest sum of cations at the upper layer and lowest $\mathrm{pH}$ at the lower layer in Eucalyptus woodlot soils should be noted for management and decision makers. There were no significant differences in soil texture, soil moisture, bulk density, total nitrogen, exchangeable magnesium, exchangeable calcium, available sulfur, and available phosphorus among the three land use types. This could avoid the negative rumors on Eucalyptus woodlots, which can be related with the aforementioned soil properties in the study area.

The study also recommended further studies on the effects of Eucalyptus on soil properties by comparing among different ages and species of Eucalyptus. Finally, planting of Eucalyptus on central highlands of Ethiopia should be supported by proper land use management decision.

\section{Abbreviations}

ANOVA: Analysis of variance

CEC: Cation exchange capacity

EC: $\quad$ Electrical conductivity

ESP: $\quad$ Exchangeable sodium percentage

$\mathrm{pH}$ : Potential of hydrogen

LSD: $\quad$ Least significant difference

RCBD: Randomized complete block design

SPSS: $\quad$ Statistical Package for Social Sciences

USDA: United States Department of Agriculture.

\section{Data Availability}

The data used to support the findings of this study are available from the corresponding author upon request.

\section{Conflicts of Interest}

The author declares that there are no conflicts of interest.

\section{Acknowledgments}

This study was funded by the International Foundation for Science (IFS) grant (no. L3-D-5826-1; 2015), and the author recognizes the support given by the organization. The author also appreciates the support given by the Central Ethiopia Environment and Forestry Research Center in Ethiopia.

\section{References}

[1] E. F. Lambin, H. J. Geist, and E. Lepers, "Dynamics of land-use and land-coverchange in tropical regions," Annual Review of Environment and Resources, vol. 28, no. 1, pp. 205-241, 2003.

[2] R. S. DeFries, J. A. Foley, and G. P. Asner, "Land-use choices: balancing human needs and ecosystem function," Frontiers in Ecology and the Environment, vol. 2, no. 5, pp. 249-257, 2004.

[3] L. Duguma, H. Hager, and M. Sieghardt, "Effects of land use types on soil chemical properties in smallholder farmers of central highland Ethiopia," Ekologia, vol. 29, no. 1, pp. 1-14, 2010.

[4] E. F. Lambin, B. L. Turner, H. J. Geist et al., "The causes of land-use and land-cover change: moving beyond the myths," Global Environmental Change, vol. 11, no. 4, pp. 261-269, 2001.

[5] Bewket, "Land cover dynamic since the 1950s in Chemoga watershed, Blue Nile basin, Ethiopia," Mountain Research and Development, vol. 22, pp. 263-269, 2002.

[6] D. Jaleta, B. Mbilinyi, H. Mahoo, and M. Lemenih, "Eucalyptus expansion as relieving and provocative tree in Ethiopia," Journal of Agriculture and Ecology Research International, vol. 6, no. 3, pp. 1-12, 2016.

[7] D. Jaleta, B. Mbilinyi, H. Mahoo, and M. Lemenih, "Evaluation of land use/land cover changes and eucalyptus expansion in Meja Watershed, Ethiopia," Journal of Geography, Environment and Earth Science International, vol. 7, no. 3, pp. 1-12, 2016.

[8] G. Fisseha, H. Gebrekidan, K. Kibret, B. Yitaferu, and B. Bedadi, "Analysis of land use/land cover changes in the debre-mewi watershed at the upper catchment of the Blue Nile basin, northwest Ethiopia," Journal of Biodiversity and Environmental Sciences, vol. 1, no. 6, pp. 184-198, 2011. 
[9] D. Jenbere, M. Lemenih, and H. Kassa, "Expansion of eucalypt farm forestry and its determinants in Arsi Negelle district, south Central Ethiopia," Small-Scale Forestry, vol. 11, no. 3, pp. 389-405, 2012.

[10] T. Chanie, A. S. Collick, E. Adgo, C. J. Lehmann, and T. S. Steenhuis, "Eco-hydrological impacts of eucalyptus in the semi humid Ethiopian highlands: the lake tana plain," Journal of Hydrology and Hydromechanics, vol. 61, no. 1, pp. 21-29b, 2013.

[11] B. Yitaferu, A. Abewa, and T. Amare, "Expansion of eucalyptus woodlots in the fertile soils of the highlands of Ethiopia: could it be a treat on future cropland use?" Journal of $\mathrm{Ag}$ ricultural Science, vol. 5, no. 8, pp. 97-107, 2013.

[12] F. Breitenbach, "Exotic forest trees in Ethiopia," Ethiopian Forest Review, vol. 2, pp. 19-39, 1961.

[13] D. Jaleta, B. P. Mbilinyi, H. F. Mahoo, and M. Lemenih, "Effect of Eucalyptus expansion on surface runoff in the central highlands of Ethiopia," Ecological Processes, vol. 6, no. 1, pp. 1-8, 2017.

[14] M. Lemenih, "Growing eucalypts by smallholder farmers in Ethiopia," in Proceedings of the Conference on Eucalyptus Species Management, History, Status and Trends in Ethiopia, L. Gil, W. Tadesse, E. Tolosana et al., Eds., 2010.

[15] Z. Kebebew and G. Ayele, "Profitability and household income contribution of growing Eucalyptus globules (Labill.) to smallholder farmers: the case of central highland of Oromia, Ethiopia," European Journal of Applied Sciences, vol. 2, no. 1, pp. 25-29, 2010.

[16] T. Bekele, "Integrated utilization of Eucalyptus globulus grown on the Ethiopian highlands and its contribution to rural livelihood: a case study of oromia, amhara and southern nations nationalities and people's regional state, Ethiopia," International Journal of Basic and Applied Sciences, vol. 4, no. 2, pp. 80-87, 2015.

[17] L. Nigatu and A. Michelsen, "Allelopathy in agroforestry systems: the effects of leaf extracts of Cupressus lusitanica and three Eucalyptus spp. on four Ethiopian crops," Agroforestry Systems, vol. 21, pp. 63-74, 1993.

[18] P. Jagger and J. Pender, "The role of trees for sustainable management of less favored lands: the case of Eucalyptus in Ethiopia," Forest Policy and Economics, vol. 5, pp. 83-95, 2003.

[19] S. Fikreyesus, Z. Kebebew, A. Nebiyu, N. Zeleke, and S. Bogale, "Allelopathic effects of Eucalyptus camaldulensis (Dehnh.) on germination and growth of tomato," Americaneurasian Journal of Agricultural and Environmental Sciences, vol. 11, no. 5, pp. 600-608, 2011.

[20] M. Lemenih, E. Karltun, and M. Olsson, "Assessing soil chemical and physical property responses to deforestation and subsequent cultivation in smallholders farming system in Ethiopia," Agriculture, Ecosystems \& Environment, vol. 105, no. 1-2, pp. 373-386, 2005.

[21] M. Muche, A. Kokeb, and E. Molla, "Assessing the physicochemical properties of soil under different land use types," Journal of Environmental \& Analytical Toxicology, vol. 5, no. 5, pp. 1-5, 2015.

[22] A. Adugna and A. Abegaz, "Effects of land use changes on the dynamics of selected soil properties in northeast Wellega, Ethiopia," Soil, vol. 2, no. 1, pp. 63-70, 2016.

[23] R. R. Jahed, S. M. Hosseini, and Y. Kooch, "The effect of natural and planted forest stands on soil fertility in the Hyrcanian region, Iran," Biodiversitas, Journal of Biological Diversity, vol. 15, no. 2, pp. 206-214, 2014.

[24] Z. Hailu, M. Sieghardt, and H. Schume, "Impact of Eucalyptus globulus and Eucalyptus camaldulensis small scale plantations on chemical and physical soil properties and on soil hydrological parameter in the highland of Ethiopia: a comparison with other land-use systems," Final Project Report, p. 183, 2003.

[25] C. T. Cortez, L. A. P. L. Nunes, L. B. Rodrigues, N. Eisenhauer, and A. S. F. Araújo, "Soil microbial properties in Eucalyptus grandis plantations of different ages," Journal of Soil Science and Plant Nutrition, vol. 14, no. 3, pp. 734-742, 2014.

[26] Z. Mekonnen, H. Kassa, M. Lemenh, and B. Campbell, "The role and management of eucalyptus in Lode Hetosa District, Central Ethiopia," Forests, Trees and Livelihoods, vol. 17, no. 4, pp. 309-323, 2007.

[27] Z. Adimassu, A. Kessler, C. Yirga, and L. Stroosnijder, "Mismatches between farmers and experts on Eucalyptus in Meskan Woreda, Ethiopia," in Proceedings of the Conference on Eucalyptus Species Management, History, Status and Trends in Ethiopia, L. Gil, W. Tadesse, E. Tolosana et al., Eds., 2010.

[28] D. Jaleta, B. P. Mbilinyi, H. F. Mahoo, and M. Lemenih, "Comparative assessment of soil and nutrient losses from three land uses in the central highlands of Ethiopia," International Journal of Water Resources and Environmental Engineering, vol. 9, no. 1, pp. 1-7, 2017.

[29] D. W. Nelson and L. E. Sommers, "Total carbon, organic carbon and organic matter," in Methods of Soil Analysis. Part 2 Chemical and Microbiological Properties, A. L. Page, R. H. Miller, and D. R. Keeney, Eds., pp. 539-579, Amer Society of Agronomy, Madison, WI, USA, 1982.

[30] J. M. Bremner, "Nitrogen total," in Methods of Soil Analysis Part 3: Chemical Methods, SSSA Book Series 5, D. L. Sparks, Ed., pp. 1085-1122, Soil Science Society of America, Madison, WI, USA, 1996.

[31] P. R. Day, "Particle size analysis," in Methods of Soil Analysis. Part 1: Physical and Mineralogical Methods, C. A. Black, Ed., pp. 545-566, American Society of Agronomy, Madison, WI, USA, 1965.

[32] W. T. Grant, "Exchangeable cations," in Methods of Soil Analysis. Part 2: Chemical and Microbiological Properties, A. L. Page and R. H. M. D. R. Keeney, Eds., Soil Science Society of America, Madison WI, USA, 2nd edition, 1982.

[33] A. Mehlich, Determination of $\mathrm{P}, \mathrm{Ca}, \mathrm{Mg}, \mathrm{K}, \mathrm{Na}$, and $\mathrm{NH}_{4}$, North Carolina Soil Test Division. Mimeo, Raleigh, NY, USA, 1953.

[34] A. Mehlich, "Mehlich 3 soil test extractant: a modification of mehlich 2 extractant," Communications in Soil Science and Plant Analysis, vol. 15, no. 12, pp. 1409-1416, 1984.

[35] R. H. Bray and L. T. Kurtz, "Determination of total, organic, and available forms of phosphorus in soils," Soil Science, vol. 59, no. 1, pp. 39-46, 1945.

[36] SPSS, IBM SPSS Statistics for Windows, IBM Corp., Armonk, NY, USA, 2011.

[37] J. R. Landon, Booker Tropical Soil Manual: A Handbook for Soil Survey and Agricultural Land Evaluation in the Tropics and Subtropics, John Wiley and Sons, New York, NY, USA, 1991.

[38] E. Nega and G. Heluf, "Effect of land use changes and soil depth on organic matter, total nitrogen, and available phosphorous contents of soils in Senbat watershed, western Ethiopia," Journal of Agricultural and Biological Science, vol. 8, pp. 206-212, 2013.

[39] Y. T. Delelegn, W. Purahong, A. Blazevic et al., "Changes in land use alter soil quality and aggregate stability in the highlands of northern Ethiopia," Scientific Reports, vol. 7, no. 1, pp. 1-12, 2017. 
[40] W. Amanuel, F. Yimer, and E. Karltun, "Soil organic carbon variation in relation to land use changes: the case of birr watershed, upper blue Nile river basin, Ethiopia," Journal of Ecology and Environment, vol. 42, no. 1, pp. 1-11, 2018.

[41] M. Chemeda, K. Kibret, and T. Fite, "Influence of different land use types and soil depths on selected soil properties related to soil fertility in Warandhab area, Horo Guduru Wallaga Zone, Oromiya, Ethiopia," International Journal of Environmental Sciences and Natural Resources, vol. 4, no. 2, pp. 1-11, 2017.

[42] F. Yimer, S. Ledin, and A. Abdelkadir, "Changes in soil organic carbon and total nitrogen contents in three adjacent land use types in the Bale mountains, south-eastern highlands of Ethiopia," Forest Ecology and Management, vol. 242, no. 2-3, pp. 337-342, 2007.

[43] N. Abate and K. Kibret, "Effects of land use, soil depth and topography on soil physicochemical properties along the toposequence at the Wadla Delanta Massif, Northcentral highlands of Ethiopia," Environment and Pollution, vol. 5, no. 2, pp. 57-71, 2016.

[44] B. Seyoum, "Assessment of soil fertility status of vertisols under selected three land uses in Girar Jarso district of north shoa zone, Oromia national regional state, Ethiopia," Environmental Systems Research, vol. 5, no. 1, pp. 1-16, 2016.

[45] D. Feyisa, E. Kissi, and Z. Kebebew, "Rethinking Eucalyptus globulus Labill. based land use systems in smallholder farmers livelihoods: a case of Kolobo Watershed, West Shewa, Ethiopia," Ekológia (Bratislava), vol. 37, no. 1, pp. 57-68, 2018.

[46] C. C. Rhodes, E. G. Eckert, and C. D. Coleman, "Soil carbon differences among forest, agriculture and secondary vegetation in lower montane Ecuador," Ecological Applications, vol. 10, no. 2, pp. 497-505, 2000.

[47] Y. Mulat, K. Kibret, B. Bedadi, and M. Mohammed, "Soil organic carbon stock under different land use types in Kersa Sub Watershed, Eastern Ethiopia," African Journal of Agricultural Research, vol. 13, no. 24, pp. 1248-1256, 2018.

[48] M. A. Tesfaye, F. Bravo, R. Ruiz-Peinado, V. Pando, and A. Bravo-Oviedo, "Impact of changes in land use, species and elevation on soil organic carbon and total nitrogen in Ethiopian Central Highlands," Geoderma, vol. 261, pp. 70-79, 2016.

[49] B. Lemma and M. Olsson, "Soil $\delta 15 \mathrm{~N}$ and nutrients under exotic tree plantations in the southwestern Ethiopian highlands," Forest Ecology and Management, vol. 237, no. 1-3, pp. 127-134, 2006.

[50] B. Bezabih, M. Lemenih, and A. Regassa, "Soil fertility status as affected by different land use types and topographic positions: a case of delta sub-watershed, southwestern Ethiopia," Journal of Biology, Agriculture and Healthcare, vol. 4, no. 27, pp. 1-16, 2014. 